\title{
Transnasal endoscopic approach to the pediatric craniovertebral junction and rostral cervical spine: case series and literature review
}

\author{
*Zachary L. Hickman, M.D., ${ }^{1}$ Michael M. McDowell, B.S., Sunjay M. Barton, B.S., ${ }^{1}$ \\ Eric S. Sussman, B.S., ${ }^{1}$ Eli Grunstein, M.D., ${ }^{2}$ and Richard C. E. Anderson, M.D. ${ }^{1}$ \\ Departments of ${ }^{I}$ Neurological Surgery and ${ }^{2}$ Otolaryngology, Columbia University Medical Center, \\ New York, New York
}

The endoscopic transnasal approach to the rostral pediatric spine and craniovertebral junction is a relatively new technique that provides an alternative to the traditional transoral approach to the anterior pediatric spine. In this case series, the authors provide 2 additional examples of patients undergoing endoscopic transnasal odontoidectomies for ventral decompression of the spinal cord. Both patients would have required transection of the palate to undergo an effective transoral operation, which can be a cause of significant morbidity. In one case, transnasal decompression was initially incomplete, and decompression was successfully achieved via a second endoscopic transnasal operation. Both cases resulted in significant neurological recovery and stable long-term spinal alignment. The transnasal approach benefits from entering into the posterior pharynx at an angle that often reduces the length of postoperative intubation and may speed a patient's return to oral intake. Higher reoperation rates are a concern for many endoscopic approaches, but there are insufficient data to conclude if this is the case for this procedure. Further experience with this technique will provide a better understanding of the indications for which it is most effective. Transcervical and transoral endoscopic approaches have also been reported and provide additional options for pediatric anterior cervical spine surgery.

(http://thejns.org/doi/abs/10.3171/2013.5.FOCUS13147)

KEY WORDS • transnasal • endoscopy • pediatric • cervical spine

$\mathrm{T}$ THE endoscopic transnasal approach to the anterior $\mathrm{CVJ}$ and the rostral cervical spine is a relatively new advancement in minimally invasive spine surgery. It was developed following increased experience with transnasal endoscopy for operations involving the skull base and adjacent structures. 1,4,11,15,17,22 First described by Alfieri et al., ${ }^{2}$ this technique has slowly expanded to fill a niche role complementary to the more traditional transoral approach to the rostral cervical spine..$^{3,9,10,13}$ Until recently, utilization of this technique in the pediatric population was deemed impractical due to restricted access to structures below C-2, a narrow corridor for instrumentation, and a greater depth separating the surgeon and the target structures. ${ }^{5}$ Several studies have demonstrated the utility of this approach in selected pediatric patients, but the full potential of this technique is still being assessed. ${ }^{14,24}$ We have previously reported on 2 of the 6 cases of endoscopic transnasal odontoidectomy for ventral cervicomedullary compression published in the pediatric literature to date. ${ }^{14}$ In this article we present our most recent experience with the transnasal endoscopic approach for the

\footnotetext{
Abbreviation used in this paper: $\mathrm{CVJ}=$ craniovertebral junction.

* Dr. Hickman and Mr. McDowell contributed equally to this work
}

same indication, adding 2 additional cases to the literature and including the first report of reoperation following an initial transnasal approach.

\section{Operative Technique}

For the endoscopic transnasal approach to the CVJ and rostral cervical spine, the patient is positioned supine followed by oral fiberoptic endotracheal intubation and initiation of electrophysiological monitoring. The head is secured in a Mayfield head holder in a slightly flexed position to allow for bilateral access to the nares by the surgeon and the assistant. The operating table is lowered sufficiently to allow for easy access to the intranasal structures to mitigate the risk of excessive torsion during instrumentation. Intraoperative frameless stereotaxic guidance or fluoroscopy is used to plan the optimal trajectory to the odontoid process of $\mathrm{C}-2$. Temporary packing of the nostrils with vasoconstrictive materials is followed by sterile prepping and draping of the patient. A rigid endoscope is then maneuvered into the nostril nearest to the assistant. The optimal trajectory is confirmed with intraoperative stereotaxy or fluoroscopy, and an adenoidectomy is performed using a microdebrider and electrocautery. 


\section{Z. L. Hickman et al.}

The dissection is continued laterally until just medial to the tori of the eustachian tubes. A partial posterior septectomy is performed if the prevertebral exposure is insufficient, using a backbiting curette. The prevertebral fascia is vertically divided in the midline, and a laryngeal spreader is used to retract the soft tissues laterally to maximize the exposure of the anterior arch of C-1 (Fig. 1).

Decompression of the ventral cervicomedullary junction is accomplished by removal of the odontoid process and all or part of the anterior arch of C-1. This is initiated through the use of the pneumatic drill with a curved extended TAC-125 drill bit (Midas Rex, Medtronic) and completed with curettes and Kerrison rongeurs. Adequate decompression is indicated when pulsation of the posterior longitudinal ligament or underlying dura mater is appreciated. Meticulous hemostasis is achieved, and the wound is copiously irrigated. Bilateral nasal packing is left in place postoperatively for hemostasis. Intubation and external immobilization of the cervical spine are typically maintained until the patient has undergone definitive stabilization of the CVJ via a posterior cervical instrumented fusion.

\section{Case Reports}

After confirming irreducible ventral brainstem compression, both patients in our current series were initially considered for a traditional transoral approach to the ventral CVJ. However, it was determined that palatal splitting would be necessary to obtain an adequate exposure, so alternatively an endoscopic transnasal approach was chosen to perform a ventral cervicomedullary decompression.

\section{Case 1}

A 12-year-old boy with Chiari I malformation, osteogenesis imperfecta, and prior gastrostomy tube placement for supplemental nutrition presented to our institution with progressive quadriparesis, vocal cord paralysis, and respiratory insufficiency. Radiographic imaging confirmed the diagnosis of basilar invagination. After initial attempts at reduction failed, a suboccipital craniectomy and C-1 laminectomy with cauterization of the tonsils and expansive duraplasty and an occiput- $\mathrm{C} 2$ instrumented fusion were performed. Intraoperative fluoroscopy and postoperative radiography demonstrated good cervical alignment. The patient recovered well and was discharged home with independent airway control, with stable quadriparesis, and at his baseline speech and swallowing function. The patient did not comply with postoperative external immobilization in a rigid cervical collar. Five months later, the patient presented to an outside institution with vocal cord paralysis, progressive weakness, anisocoria, and central apnea requiring intubation. Computed tomography and MRI demonstrated anterior cervicomedullary compression and upward mass effect on the midbrain due to a retroflexed odontoid process. Decompression was planned via an endoscopic transnasal approach (Fig. 2).

Initial Transnasal Approach. The details of the operative technique are as described above. A complete C-1 anterior arch and odontoid process resection appeared

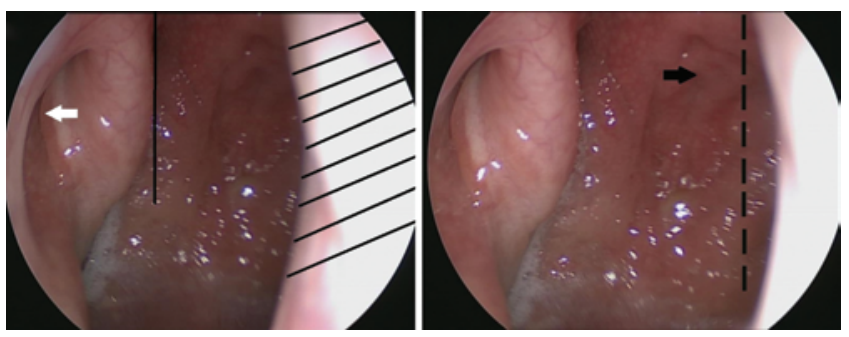

Fig. 1. Endoscopic view of the pediatric posterior nasopharynx. Left: Endoscopic approach to the posterior nasopharynx. Vertical bar indicates lateral boundary defined by the torus of the eustachian tube. Diagonal bars indicate area of posterior septum removed during posterior septectomy. White arrow designates the eustachian tube. Right: Endoscopic view prior to midline incision. Black arrow indicates the adenoid bed targeted for adenoidectomy. Dotted line designates location of the initial midline incision.

to have been achieved by visual inspection and was confirmed with frameless stereotaxic guidance. There was no evidence of inadvertent durotomy or CSF leak. After completion of the neurosurgical portion of the operation, a tracheostomy was performed by the otolaryngology team.

Initial Postoperative Course. The patient was stable postoperatively except for a transient episode of hypotension that was treated successfully with vasopressors. The results of his neurological examination were encouraging, with improved speech and increased motor strength. A diet was restarted on postoperative Day 7; however, the patient continued to remain ventilator dependent 2 weeks following surgery. This prompted an investigation with additional CT imaging, which showed incomplete resection of the odontoid process. Due to concern for inadequate cervicomedullary decompression, the patient was taken back to the operating room on postoperative Day 14 to complete the odontoid process resection (Fig. 3).

Second Transnasal Approach. The patient was positioned and draped in the same manner as for the initial surgery. The endoscope was positioned to visualize the prior operative site. The vertical incision in the prevertebral fascia was noted to be healing well. This incision was reopened and a laryngeal retractor was placed to allow for adequate visualization of the resection cavity. Frameless stereotactic guidance was used to confirm the location of the remaining portion of the odontoid process. The residual bone was palpated using a straight curette and the intervening soft tissue was gently displaced out of the approach trajectory. The odontoid process was drilled down to a thin layer of posterior cortical bone using a pneumatic drill and TAC-125 drill bit (Midas Rex, Medtronic). Using a combination of curettes and Kerrison rongeurs, the posterior cortical wall of the odontoid process and posterior longitudinal ligament were removed in a piecemeal fashion. The dura was clearly visualized and noted to be pulsatile with no evidence of durotomy. An angled curette was used to directly palpate the base of the C-2 body and the basion of the clivus to ensure that there was adequate decompression both laterally and rostrally. Hemostasis and closure were performed in the same manner as discussed previously. There were no complications encountered during the surgery. Complete resection of the 


\section{Pediatric transnasal endoscopic spine surgery}
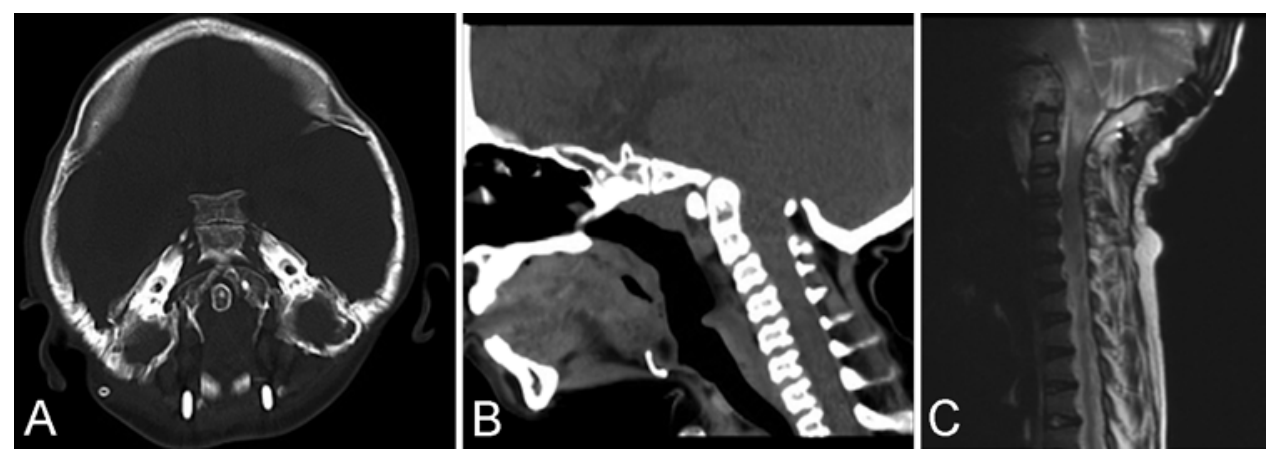

FIG. 2. Case 1. Preoperative neuroimaging. A: Axial CT scan demonstrating the location of the odontoid process at the level of the clivus. B: Sagittal CT scan showing retroflexed odontoid. C: Sagittal T2-weighted MR image demonstrating cervicomedullary edema.

odontoid process and good ventral cervicomedullary decompression was confirmed via immediate postoperative CT prior to reversal of general anesthesia.

Second Postoperative Course. The patient did well following his second surgery with resumption of oral feedings with gastrostomy tube supplementation on postoperative Day 1. His neurological exam continued to improve and he had daytime ventilator independence by postoperative Day 10. Postoperative MRI demonstrated mild to moderate cervicomedullary edema. He was discharged to a rehabilitation facility 28 days after his second operation. By 9 months following his second surgery, the patient was noted to have a durable neurological recovery and had successfully been weaned off all mechanical ventilation. Repeat imaging at that time demonstrated a stable decompression of the cervicomedullary junction, a solid occiput-C2 fusion, and a dramatic reduction of the previously noted cervicomedullary swelling (Fig. 4).

\section{Case 2}

An 11-year-old boy with Down syndrome and autism presented to our institution with neck pain, reduced food intake and weight, and severe progressive quadriparesis and myelopathy. Computed tomography and MRI demonstrated basilar invagination with a retroflexed odontoid process and ventral cervicomedullary compression. A chronic inflammatory pannus at this location significantly added to the degree of compression. After attempts at reduction failed, an endoscopic transnasal decompression of the cervicomedullary junction with subsequent posterior decompression and fusion was performed (Fig. 5).

Transnasal Approach. The details of the operative technique are as described above. Resection of the odontoid process was confirmed intraoperatively and with frameless stereotactic guidance. There were no complications and no evidence of durotomy or CSF leak during the operation (Fig. 6).

Postoperative Course. On postoperative Day 3 the patient underwent a suboccipital craniectomy, $\mathrm{C}-1$ laminectomy, and occiput-C2 instrumented fusion without complication. Partial but not complete reduction of the C1-2 subluxation was obtainable. The patient was extubated the following day and began oral intake the day after. Postop- erative CT imaging confirmed resolution of the cervicomedullary compression.

The patient improved neurologically and had substantial motor strength gains in all extremities. By the time of discharge, he was ambulating with assistance and was able to accomplish functional tasks such as dressing and feeding himself. A formal evaluation demonstrated minimal swallowing impairment, and although the patient was functionally capable of normal oral intake, he was intermittently noncompliant. He was discharged to rehabilitation from the neurosurgical service with follow-up from a nutrition specialist. By 5 months postoperatively, the patient was achieving adequate nutrition entirely by mouth and was ambulating independently with only mild residual weakness of his lower extremities. Repeat CT imaging at this time demonstrated durable decompression of the cervicomedullary junction and a solid occiput-C2 fusion.

\section{Discussion}

Advantages and Disadvantages of the Endoscopic Transnasal Approach to the Ventral CVJ and Rostral Cervical Spine

The use of endoscopic transnasal approaches to the ventral pediatric CVJ and rostral cervical spine raises concerns regarding the appropriate expansion of a technique still in its infancy into territory historically within the domain of transoral approaches, which are more established and widely practiced. It is our opinion that there are several distinct advantages of the endoscopic transnasal approach over a traditional transoral approach that
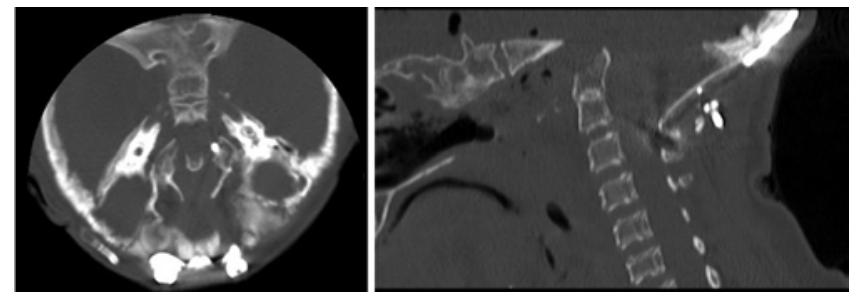

Fig. 3. Case 1. Postoperative images after the first transnasal odontoidectomy. Left: Axial CT scan demonstrating partial resection of the dens at the level of the clivus. Right: Sagittal CT scan demonstrating partial resection of the superior odontoid process. 

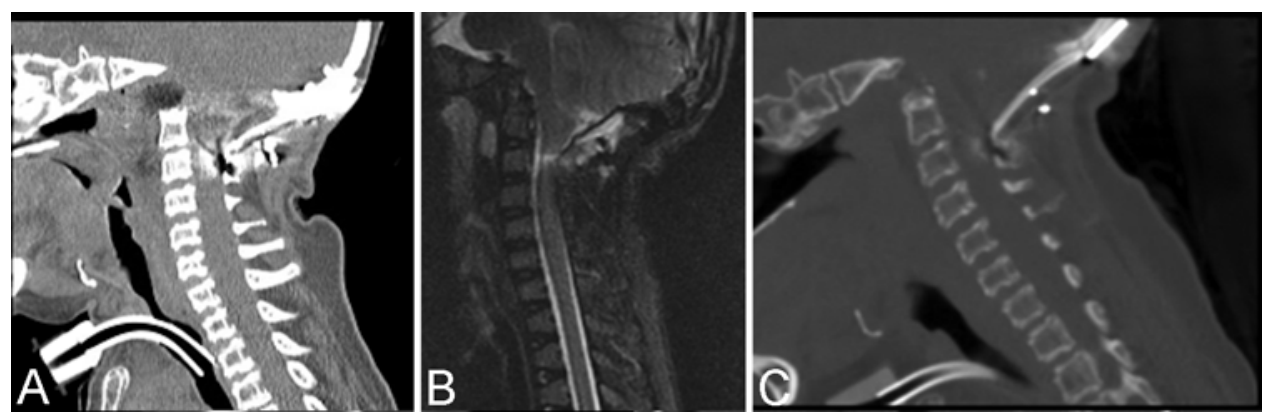

FIG. 4. Case 1. Postoperative neuroimages after the second transnasal odontoidectomy. A: Sagittal CT scan demonstrating complete resection of the odontoid. edema and possible chronic gliosis. ment and decompression.

B: Follow-up sagittal T2-weighted MR image demonstrating reduced cervicomedullary C: Follow-up sagittal CT scan demonstrating the long-term maintenance of spinal align-

ultimately dictate its safe and effective utilization. The oral cavity in some patients, such as those who are very young or those with macroglossia, midface hypoplasia, and micrognathia, may be insufficient to allow for an adequate degree of retraction when attempting a transoral approach. ${ }^{21,24,36}$ Overly aggressive efforts to operate with insufficient exposure may increase the risk of traumatic injuries to the soft and bony architecture of the oral cavity.

A transnasal approach may be considered in cases when there is a significant need to avoid oral trauma. Patients in whom routine postoperative extubation is already a concern may benefit from reduced manipulation and subsequent edema of the oropharyngeal soft tissues. Trauma to the retronasal pharyngeal tissues during a transnasal approach results in swelling that is often less obstructive to respiration; in adult patients this has been shown to lessen the time until extubation and the risk of reintubation. ${ }^{7,1921,28,38}$ Rates of significant upper respiratory tract edema requiring intervention following transoral approaches have been reported in up to $5 \%$ of adults and $4 \%$ of children, but this rate may be artificially low due to a more cautious timetable for extubation. $6,9,13,20,26,27,36,39,40 \mathrm{Ad}-$ ditionally, an endoscopic transnasal approach may allow for a more prompt return to a normal oral diet..$^{21,24}$

The incidence of new-onset dysphagia after a traditional transoral approach ranges from $0 \%-20 \%$ in adults and $0 \%-4 \%$ in the pediatric population, which is not unexpected given the dissection of the posterior pharyngeal tissues that is required. ${ }^{6,9,13,26,27,34,36,39,40} \mathrm{~A}$ final potential advantage of endoscopic transnasal approaches versus transoral approaches is greater access to the structures superior to the soft palate, facilitating a more direct trajectory to the rostral CVJ. This reduces the frequent need to split the palate, which may be required in up to $29 \%$ of adult patients undergoing transoral surgery. ${ }^{6}$ In the pediatric population, the need for palatal splitting may be even higher given the smaller oral cavity. Tuite et al. reported soft palate splitting in $48 \%$ of patients undergoing a transoral approach, with $33 \%$ of cases requiring additional splitting of the hard palate. ${ }^{36}$ In cases where an endoscopic transnasal approach is feasible, avoidance of palatal splitting may result in decreased morbidity and long-term dysfunction such as velopharyngeal insufficiency. ${ }^{6}$ In our current case series, a major factor in the decision to perform an initial endoscopic transnasal approach to the ventral CVJ was the determination that palatal splitting would have been required during a traditional transoral approach for both children.

There are, however, several limitations to current endoscopic transnasal techniques. While the endoscope provides excellent visualization and illumination of the ventral CVJ, the hard palate restricts direct trajectories to the subaxial spine, resulting in limited access to this region. Overcoming this limitation requires lowering of the nasopalatine line via drilling of the hard palate, reducing the primary advantage of the transnasal approach. ${ }^{24}$ Ideal targets for a transnasal approach are situated in the anterior aspect of the rostral cervical spine. Relatively small nasal
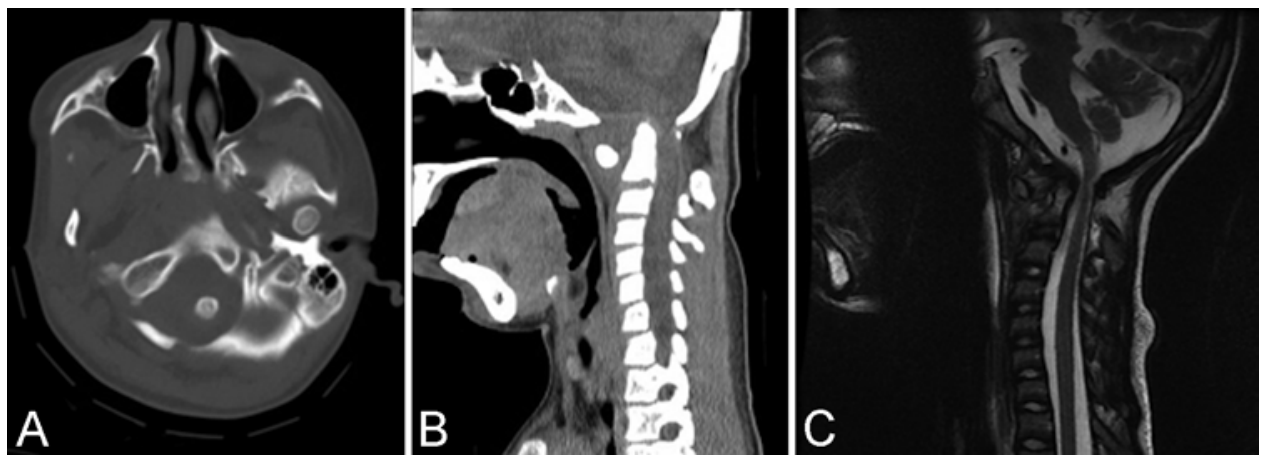

FIG. 5. Case 2. Preoperative neuroimages. A: Axial CT scan demonstrating position of the odontoid at the level of the foramen magnum. B: Sagittal CT scan revealing the retroflexed odontoid process. C: Sagittal T2-weighted MR image demonstrating compression of the cervicomedullary junction. 


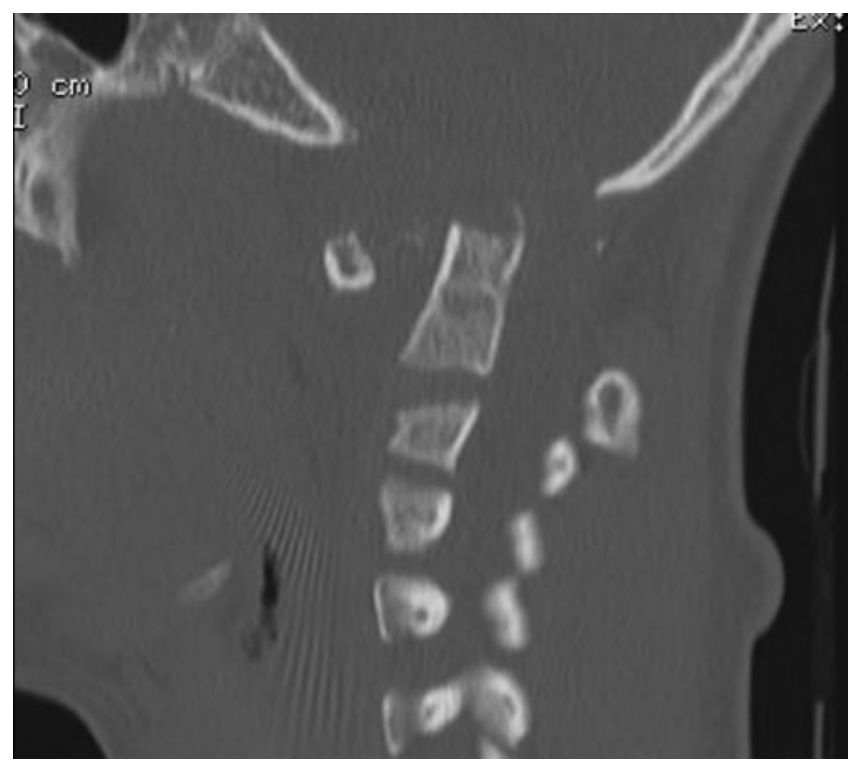

FIG. 6. Case 2. Postoperative neuroimaging. Sagittal CT demonstrating resection of the odontoid and persistent $\mathrm{C} 1-2$ instability necessitating a posterior decompression and fusion on Day 3.

cavities may necessitate widening via an inferior turbinate reduction or middle turbinectomy, which has the potential to permanently alter the natural flow of air during nasal respiration. ${ }^{21}$ An alternative option is to perform a posterior septal resection via back-biting curettes, as described above, or a septoplasty.

In our case series, we report the first incident of a pediatric transnasal odontoidectomy requiring reoperation. In this specific case, one contributing factor was a loss of accuracy of the stereotactic navigation system because of the loosening of the head pins due to the thin bone inherent in osteogenesis imperfecta. Nevertheless, there is ongoing controversy as to whether similar minimally invasive approaches have a higher incidence of reoperation compared with more traditional open approaches for select procedures. ${ }^{16,18,23,31,32}$ The trajectory required to reach the odontoid process via an endoscopic transnasal approach may result in certain lesions being difficult to access or visualize. Reoperations due to incomplete resection of the odontoid process have been very rarely reported with the transoral approach, with Yerramneni et al. reporting only a single incident in their series of 59 cases. Reoperation for other indications occurred in 3 other patients. ${ }^{40}$ Further experience with the endoscopic transnasal approach and analyses of larger case series will be required to determine if the incidence of reoperation is indeed higher than that of traditional transoral approaches to the CVJ and rostral cervical spine. With increased use of spinal navigation systems, intraoperative CT quality imaging is likely to reduce the incidence of incomplete resection and reoperation.

A further concern is the increased difficulty of durotomy repair and prevention of CSF leak during endoscopic transnasal approaches. A reduction in the degrees of freedom when using transnasal instrumentation theoretically increases the difficulty of obtaining a satisfactory closure of the dura and overlying pharyngeal tissues. This may increase the risk of CSF leak and predispose patients to meningitis secondary to invasion by oral flora or fistula formation. ${ }^{14,24,38}$ Techniques such as packing the nasopharynx with a fat graft or the use of fibrin glue may supplement suturing of the soft tissues in these circumstances.

\section{Transnasal Odontoid Resection in the Pediatric Population}

Ventral decompression of the cervicomedullary junction via resection of the anterior arch of C-1 and the odontoid process is, to date, among the most frequently reported indications for utilizing an endoscopic transnasal approach in children, with a total of 6 previously published cases (mean age 11.8 years; range $10-15$ years). ${ }^{14,24,30,33,35}$ One of these cases was performed at our institution. ${ }^{14}$ While different etiologies were responsible, the unifying feature in each case was irreducible compression of the cervicomedullary junction. In all but one case, there was a preexisting condition associated with the compression (Chiari malformation Type I in 2 patients, Chiari malformation Type II in 1 patient, Down syndrome in 1 patient, and osteogenesis imperfecta in 1 patient). Two patients presented with quadriparesis and respiratory compromise, 1 patient with progressive bulbar symptoms and myelopathy, another with mild myelopathy, 1 with progressive scoliosis, and a final patient with isolated neck pain and decreased range of motion. Of these 6 cases, 2 had previously undergone posterior decompression that failed to resolve the cervicomedullary compression and another had an aborted posterior approach due to loss of motor potentials during instrumentation (Table 1). ${ }^{24,30,33}$ The ability to do a posterior decompression and fusion prior to an anterior approach is another major advantage of the transnasal approach. The transoral approach is best performed with neck extension, necessitating a posterior fusion after, rather than before, ventral decompression is attempted. It is our experience that many patients, especially with Chiari malformation, with mild or moderate ventral compression improve with posterior decompression alone. However, if an anterior approach is still required, the transnasal endoscopic approach can be readily performed with the neck in the neutral position.

One case in the literature was complicated by an unintended durotomy. ${ }^{24}$ Repair was performed through use of a fat graft and a mucosal flap. No CSF leak was reported postoperatively. No other operative complications were noted and none of the previously reported cases required a return to the operating room during the follow-up period. By contrast, in their series of 59 cases of ventral cervicomedullary decompression using a transoral approach, Yerramneni et al. reported a postoperative CSF leak or meningitis in 5 patients $(8.5 \%) .{ }^{40}$ Despite concerns for an elevated risk of unintended durotomy and an increased difficulty of repair when using an endoscopic transnasal approach rather than a transoral approach, limited current data do not support this conclusion.

With the addition of our 2 current cases to 6 six cases previously reported in the literature, there were a total of 4 patients who had posterior cervical instrumented fusion performed shortly following ventral odontoidectomy. ${ }^{14,30}$ All patients were able to return to a normal oral diet without a need for gastrostomy, except in 1 case where the patient had a preexisting gastrostomy tube placement. The 
Z. L. Hickman et al.

TABLE 1: Presenting characteristics and operative complications in pediatric patients undergoing endoscopic transnasal odontoidectomy

\begin{tabular}{|c|c|c|c|c|c|c|}
\hline $\begin{array}{l}\text { Case } \\
\text { No. }\end{array}$ & Authors \& Year & $\begin{array}{l}\text { Age (yrs), } \\
\text { Sex }\end{array}$ & Medical History & Indication for Op & Presenting Symptoms & $\begin{array}{c}\text { Op } \\
\text { Complications }\end{array}$ \\
\hline 1 & $\begin{array}{l}\text { Magrini et al., } \\
2008\end{array}$ & $11, M$ & Down syndrome & $\begin{array}{l}\text { atlantoaxial subluxation, } \\
\text { os odontoideum }\end{array}$ & $\begin{array}{l}\text { progressive quadriparesis, respiratory dis- } \\
\text { turbances during sleep }\end{array}$ & $\begin{array}{l}\text { CSF leak re- } \\
\text { paired w/ } \\
\text { fat graft }\end{array}$ \\
\hline 2 & $\begin{array}{l}\text { Hankinson et } \\
\text { al., 2010* }\end{array}$ & $15, M$ & $\begin{array}{l}\text { Chiari malformation } \\
\text { Type I }\end{array}$ & $\begin{array}{l}\text { retroflexed odontoid pro- } \\
\text { cess }\end{array}$ & $\begin{array}{l}\text { recurrent occipital headaches, hypernasal } \\
\text { speech, palatal \& swallowing dysfunc- } \\
\text { tion, loss of gag reflex, myelopathy }\end{array}$ & none \\
\hline 3 & - & $11, \mathrm{~F}$ & $\begin{array}{l}\text { Chiari malformation } \\
\text { Type I }\end{array}$ & $\begin{array}{l}\text { retroflexed odontoid pro- } \\
\text { cess }\end{array}$ & scoliosis, syringomyelia & none \\
\hline 4 & $\begin{array}{l}\text { Tomazic et al., } \\
2011\end{array}$ & $11, \mathrm{~F}$ & $\begin{array}{l}\text { Chiari malformation } \\
\text { Type II }\end{array}$ & $\begin{array}{l}\text { retroflexed odontoid pro- } \\
\text { cess }\end{array}$ & myelopathy, syringomyelia & none \\
\hline 5 & $\begin{array}{l}\text { Sinha et al., } \\
2012\end{array}$ & $13, \mathrm{~F}$ & osteogenesis imperfecta & basilar invagination & $\begin{array}{l}\text { progressive quadriparesis, dysphagia, res- } \\
\text { piratory dysfunction, hydrocephalus }\end{array}$ & none \\
\hline 6 & $\begin{array}{l}\text { Patel et al., } \\
\quad 2012\end{array}$ & $10, \mathrm{~F}$ & none & atlantoaxial rotary fixation & neck pain, decreased range of motion & none \\
\hline 7 & present study & $12, \mathrm{M}$ & $\begin{array}{l}\text { osteogenesis imperfecta } \\
\text { \& Chiari malformation } \\
\text { Type I }\end{array}$ & $\begin{array}{l}\text { retroflexed odontoid pro- } \\
\text { cess }\end{array}$ & $\begin{array}{l}\text { progressive quadriparesis, respiratory dys- } \\
\text { function, vocal cord paralysis, dyspha- } \\
\text { gia }\end{array}$ & $\begin{array}{l}\text { repeat op nec- } \\
\text { essary }\end{array}$ \\
\hline 8 & - & $11, M$ & Down syndrome & $\begin{array}{l}\text { retroflexed odontoid pro- } \\
\text { cess }\end{array}$ & $\begin{array}{l}\text { progressive quadriparesis, decreased oral } \\
\text { intake, neck pain }\end{array}$ & none \\
\hline
\end{tabular}

* Performed at our center by the same pediatric neurosurgeon (R.C.E.A.).

mean duration until initiation of oral intake following surgery was 3.1 days (range 1-7 days). Extubation occurred at a mean of 2 days postoperatively (range 1-4 days), excluding our current case in which tracheostomy and long-term ventilation were required. One other patient previously reported in the literature required short-term tracheostomy; this patient had been extubated on postoperative Day 1 but required an emergent tracheostomy due to oversedation. ${ }^{14}$ The tracheostomy was reversed on postoperative Day 7. Mean follow-up for all patients was 8.1 months (range 2-18 months). Including our 2 new cases reported here, 4 patients initially presented with severe quadriparesis. ${ }^{24,33}$ Three patients had significant gains in both motor strength and respiratory function, and the fourth had sufficient improvement of lower-extremity function to be able to ambulate, as well as improved respiratory function. ${ }^{33}$ Of the 3 patients with Chiari malformation Type I, the 2 patients with bulbar and spinal cord dysfunction had significant improvement in their symptoms, whereas the third patient with syringomyelia and scoliosis demonstrated involution of the syrinx and no further curve progression. ${ }^{14}$ The 1 patient with Chiari malformation Type II had complete resolution of symptoms (Table 2). ${ }^{35}$

\section{Alternative Endoscopic Approaches to the Pediatric Cervical Spine}

In addition to the transnasal approach to pediatric cervical spine lesions, use of endoscopy has been reported in combination with both transoral and transcervical approaches. Recently, McGirt et al. published the first series of odontoidectomies using an endoscopic transcervical approach in the pediatric population. ${ }^{25}$ Four patients were included, all presenting with myelopathy secondary to ventral cervicomedullary compression. All were able to be extubated expeditiously after surgery and none required postoperative placement of a gastrostomy tube (although 1 patient required a gastrostomy prior to surgery). These results are similar to those seen so far in patients treated with an endoscopic transnasal approach.

The endoscopic transcervical approach to the rostral cervical spine has a potential advantage in that the anatomy of the exposure may be more familiar to most neurosurgeons than that of a transnasal approach. Additionally, the transcervical approach completely avoids the risk of infection secondary to contamination by pharyngeal flora. However, data from published pediatric and adult cohorts are insufficient to draw conclusions regarding the relative infection rates of endoscopic transnasal and transcervical approaches to the cervical spine. ${ }^{8,37}$ Potential disadvantages of the transcervical approach to the rostral cervical spine generally relate to the fact that it does not make use of the natural operating space provided by the nasopharynx or oropharynx, as do the transnasal and transoral approaches, respectively. In addition to reducing potential "angles of attack" to the anterior arch of C-1 and the odontoid process, this may result in a higher likelihood of postoperative respiratory or swallowing dysfunction due to excessive retraction. ${ }^{5}$ In a recent series of 15 adult patients, $2(13 \%)$ had sufficient upper respiratory tract edema to require treatment with systemic steroids and $1(6.7 \%)$ developed severe dysphagia necessitating gastrostomy tube placement. ${ }^{8}$

The use of endoscopy combined with a transoral approach to the CVJ and rostral cervical spine has yet to be reported in pediatric patients, although technical feasibility has been demonstrated in cases of posterior oro- 


\section{Pediatric transnasal endoscopic spine surgery}

TABLE 2: Postoperative and long-term outcomes of pediatric patients undergoing endoscopic transnasal odontoidectomy

\begin{tabular}{|c|c|c|c|c|c|c|c|}
\hline $\begin{array}{l}\text { Case } \\
\text { No. }\end{array}$ & $\begin{array}{l}\text { Days Until } \\
\text { Extubation }\end{array}$ & $\begin{array}{l}\text { Days } \\
\text { Until } \\
\text { Oral } \\
\text { Intake }\end{array}$ & $\begin{array}{l}\text { Gastrostomy } \\
\text { Needed }\end{array}$ & Tracheostomy Needed & $\begin{array}{c}\text { Posterior } \\
\text { Decompression }\end{array}$ & $\begin{array}{l}\text { Follow- } \\
\text { Up } \\
\text { (mos) }\end{array}$ & Follow-Up Outcome \\
\hline 1 & 3 & 3 & no & no & prior to odontoidectomy & 2 & $\begin{array}{l}\text { quadriparesis improvement; no further } \\
\text { respiratory disturbances }\end{array}$ \\
\hline 2 & 2 & 6 & no & $\begin{array}{l}\text { emergency tracheostomy } \\
\text { postop due to overse- } \\
\text { dation }\end{array}$ & after odontoidectomy & 9 & $\begin{array}{l}\text { resolution of headaches, improvement } \\
\text { of myelopathy, normalization of } \\
\text { speech \& swallowing }\end{array}$ \\
\hline 3 & 2 & 1 & no & no & after odontoidectomy & 18 & $\begin{array}{l}\text { resolution of syringomyelia, nonpro- } \\
\text { gression of scoliosis }\end{array}$ \\
\hline 4 & 1 & 1 & no & no & prior to odontoidectomy & 12 & $\begin{array}{l}\text { resolution of compression \& syringo- } \\
\text { myelia }\end{array}$ \\
\hline 5 & 1 & 1 & no & no & no & 3 & $\begin{array}{l}\text { resolution of hydrocephalus, respirato- } \\
\text { ry dysfunction, \& dysphagia; im- } \\
\text { provement in walking }\end{array}$ \\
\hline 6 & 1 & 1 & no & no & $\begin{array}{l}\text { attempted prior, repeat- } \\
\text { ed after odontoidec- } \\
\text { tomy }\end{array}$ & 7 & normal \\
\hline 7 & $\begin{array}{l}\text { discharged } w / \\
\text { tracheostomy }\end{array}$ & 7 & preexisting & yes & prior to odontoidectomy & 9 & $\begin{array}{l}\text { independent respiration, } 4 / 5 \text { motor } \\
\text { strength in all extremities, improved } \\
\text { speech \& swallowing }\end{array}$ \\
\hline 8 & 4 & 5 & no & no & after odontoidectomy & 5 & $\begin{array}{l}\text { improved strength ( } 4 / 5 \text { lower, } 5 / 5 \text { up- } \\
\text { per), improved oral intake }\end{array}$ \\
\hline
\end{tabular}

pharynx lesions. ${ }^{29}$ The adult literature contains 7 reported cases of the CVJ being accessed through an endoscopic transoral approach. ${ }^{12}$ Frempong-Boadu et al. reported successful decompression of the cervicomedullary junction in all cases without operative complications. All patients were extubated within 72 hours postoperatively, with the exception of 1 patient who had initially presented with a tracheostomy. Six of the 7 patients demonstrated neurological improvement on follow-up; unfortunately, 1 patient died of a myocardial infarction 1 month after surgery. ${ }^{12}$ It still remains to be seen if the combined use of endoscopy and a transoral approach will find a niche within the neurosurgical armamentarium.

\section{Conclusions}

The use of the endoscopic transnasal approach to the anterior CVJ and rostral pediatric cervical spine is still in its infancy but has the potential to be invaluable in appropriate patients. Further experience with this technique will allow for a better comparison of its advantages and disadvantages as against traditional transoral, endoscopic transoral, and endoscopic transcervical approaches. Transnasal endoscopy appears to attenuate the risk of postoperative pharyngeal and upper respiratory tract compromise but may present technical challenges, including obtaining an adequate trajectory to the target and, if required, performing a satisfactory dural repair. In addition to reporting on 2 new cases of cervicomedullary decompression through an endoscopic transnasal approach, we demonstrate that reoperation using this approach after a prior attempt at transnasal decompression can be accomplished both safely and effectively.

\section{Disclosure}

Mr. McDowell and Mr. Sussman are recipients of a Clinical Research Fellowship from the Doris Duke Charitable Foundation.

Author contributions to the study and manuscript preparation include the following. Conception and design: Anderson, Hickman, McDowell. Acquisition of data: Hickman, McDowell, Barton. Analysis and interpretation of data: Anderson, Hickman, McDowell, Barton. Drafting the article: Anderson, Hickman, McDowell, Barton. Critically revising the article: all authors. Reviewed submitted version of manuscript: all authors. Approved the final version of the manuscript on behalf of all authors: Anderson.

\section{References}

1. Alfieri A, Jho HD: Endoscopic endonasal cavernous sinus surgery: an anatomic study. Neurosurgery 48:827-837, 2001

2. Alfieri A, Jho HD, Tschabitscher M: Endoscopic endonasal approach to the ventral cranio-cervical junction: anatomical study. Acta Neurochir (Wien) 144:219-225, 2002

3. Apuzzo ML, Weiss MH, Heiden JS: Transoral exposure of the atlantoaxial region. Neurosurgery 3:201-207, 1978

4. Aust MR, McCaffrey TV, Atkinson J: Transnasal endoscopic approach to the sella turcica. Am J Rhinol 12:283-287, 1998

5. Baird CJ, Conway JE, Sciubba DM, Prevedello DM, QuiñonesHinojosa A, Kassam AB: Radiographic and anatomic basis of endoscopic anterior craniocervical decompression: a comparison of endonasal, transoral, and transcervical approaches. Neurosurgery 65 (6 Suppl):158-163, 2009

6. Choi D, Melcher R, Harms J, Crockard A: Outcome of 132 operations in 97 patients with chordomas of the craniocervical 
junction and upper cervical spine. Neurosurgery 66:59-65, 2010

7. Crockard HA: Transoral surgery: some lessons learned. Br J Neurosurg 9:283-293, 1995

8. Dasenbrock HH, Clarke MJ, Bydon A, Sciubba DM, Witham TF, Gokaslan ZL, et al: Endoscopic image-guided transcervical odontoidectomy: outcomes of 15 patients with basilar invagination. Neurosurgery 70:351-360, 2012

9. Di Lorenzo N: Craniocervical junction malformation treated by transoral approach. A survey of 25 cases with emphasis on postoperative instability and outcome. Acta Neurochir (Wien) 118:112-116, 1992

10. Estridge MN, Smith RA: Transoral fusion of odontoid fracture. Case report. J Neurosurg 27:462-465, 1967

11. Frank G, Pasquini E: Endoscopic endonasal cavernous sinus surgery, with special reference to pituitary adenomas. Front Horm Res 34:64-82, 2006

12. Frempong-Boadu AK, Faunce WA, Fessler RG: Endoscopically assisted transoral-transpharyngeal approach to the craniovertebral junction. Neurosurgery 51 (5 Suppl):S60-S66, 2002

13. Hadley MN, Spetzler RF, Sonntag VK: The transoral approach to the superior cervical spine. A review of 53 cases of extradural cervicomedullary compression. J Neurosurg 71:16-23, 1989

14. Hankinson TC, Grunstein E, Gardner P, Spinks TJ, Anderson RC: Transnasal odontoid resection followed by posterior decompression and occipitocervical fusion in children with Chiari malformation Type I and ventral brainstem compression. Report of 2 cases. J Neurosurg Pediatr 5:549-553, 2010

15. Heilman CB, Shucart WA, Rebeiz EE: Endoscopic sphenoidotomy approach to the sella. Neurosurgery 41:602-607, 1997

16. Janson M, Björholt I, Carlsson P, Haglind E, Henriksson M, Lindholm E, et al: Randomized clinical trial of the costs of open and laparoscopic surgery for colonic cancer. Br J Surg 91:409-417, 2004

17. Jho HD, Ha HG: Endoscopic endonasal skull base surgery: Part 2-the cavernous sinus. Minim Invasive Neurosurg 47:9-15, 2004

18. Kim CH, Chung CK, Park CS, Choi B, Kim MJ, Park BJ: Reoperation rate after surgery for lumbar herniated intervertebral disc disease: nationwide cohort study. Spine (Phila Pa 1976) 38:581-590, 2013

19. Kingdom TT, Nockels RP, Kaplan MJ: Transoral-transpharyngeal approach to the craniocervical junction. Otolaryngol Head Neck Surg 113:393-400, 1995

20. Landeiro JA, Boechat S, Christoph DdeH, Gonçalves MB, Castro Id, Lapenta MA, et al: Transoral approach to the craniovertebral junction. Arq Neuropsiquiatr 65 (4B):1166-1171, 2007

21. Laufer I, Greenfield JP, Anand VK, Härtl R, Schwartz TH: Endonasal endoscopic resection of the odontoid process in a nonachondroplastic dwarf with juvenile rheumatoid arthritis: feasibility of the approach and utility of the intraoperative Iso$\mathrm{C}$ three-dimensional navigation. Case report. J Neurosurg Spine 8:376-380, 2008

22. Liu HS, Di X: Endoscopic endonasal surgery for biopsy of cavernous sinus lesions. Minim Invasive Neurosurg 52:69-73, 2009

23. Madersbacher S, Lackner J, Brössner C, Röhlich M, Stancik $\mathrm{I}$, Willinger M, et al: Reoperation, myocardial infarction and mortality after transurethral and open prostatectomy: a nationwide, long-term analysis of 23,123 cases. Eur Urol 47:499504, 2005

24. Magrini S, Pasquini E, Mazzatenta D, Mascari C, Galassi E, Frank G: Endoscopic endonasal odontoidectomy in a patient affected by Down syndrome: technical case report. Neurosurgery 63:E373-E374, 2008
25. McGirt MJ, Attenello FJ, Sciubba DM, Gokaslan ZL, Wolinsky JP: Endoscopic transcervical odontoidectomy for pediatric basilar invagination and cranial settling. Report of 4 cases. J Neurosurg Pediatr 1:337-342, 2008

26. Menezes AH, Graf CJ, Hibri N: Abnormalities of the craniovertebral junction with cervico-medullary compression. A rational approach to surgical treatment in children. Childs Brain 7:15-30, 1980

27. Merwin GE, Post JC, Sypert GW: Transoral approach to the upper cervical spine. Laryngoscope 101:780-784, 1991

28. Nayak JV, Gardner PA, Vescan AD, Carrau RL, Kassam AB, Snyderman $\mathrm{CH}$ : Experience with the expanded endonasal approach for resection of the odontoid process in rheumatoid disease. Am J Rhinol 21:601-606, 2007

29. Öztürk O, Polat S: Comparison of transoral power-assisted endoscopic adenoidectomy to curettage adenoidectomy. Adv Ther 29:708-721, 2012

30. Patel AJ, Boatey J, Muns J, Bollo RJ, Whitehead WE, Giannoni CM, et al: Endoscopic endonasal odontoidectomy in a child with chronic type 3 atlantoaxial rotatory fixation: case report and literature review. Childs Nerv Syst 28:1971-1975, 2012

31. Pierik EG, van Urk H, Hop WC, Wittens CH: Endoscopic versus open subfascial division of incompetent perforating veins in the treatment of venous leg ulceration: a randomized trial. J Vasc Surg 26:1049-1054, 1997

32. Sekhar N, Torquati A, Youssef Y, Wright JK, Richards WO: A comparison of 399 open and 568 laparoscopic gastric bypasses performed during a 4-year period. Surg Endosc 21:665-668, 2007

33. Sinha S, Mirza S, Bishop N, Zaki H, McMullan J: Endoscopic endonasal resection of the odontoid peg for paediatric basilar invagination. Br J Neurosurg 26:487-489, 2012

34. Ternier J, Joshi SM, Thompson DN: Image-guided transoral surgery in childhood. Childs Nerv Syst 25:563-568, 2009

35. Tomazic PV, Stammberger H, Mokry M, Gerstenberger C, Habermann W: Endoscopic resection of odontoid process in Arnold Chiari malformation type II. B-ENT 7:209-213, 2011

36. Tuite GF, Veres R, Crockard HA, Sell D: Pediatric transoral surgery: indications, complications, and long-term outcome. J Neurosurg 84:573-583, 1996

37. Wolinsky JP, Sciubba DM, Suk I, Gokaslan ZL: Endoscopic image-guided odontoidectomy for decompression of basilar invagination via a standard anterior cervical approach. Technical note. J Neurosurg Spine 6:184-191, 2007

38. Wu JC, Huang WC, Cheng H, Liang ML, Ho CY, Wong TT, et al: Endoscopic transnasal transclival odontoidectomy: a new approach to decompression: technical case report. Neurosurgery 63 (1 Suppl 1):ONSE92-ONSE94, 2008

39. Yang SY, Gao YZ: Clinical results of the transoral operation for lesions of the craniovertebral junction and its abnormalities. Surg Neurol 51:16-20, 1999

40. Yerramneni VK, Chandra PS, Kale SS, Lythalling RK, Mahapatra AK: A 6-year experience of 100 cases of pediatric bony craniovertebral junction abnormalities: treatment and outcomes. Pediatr Neurosurg 47:45-50, 2011

Manuscript submitted April 15, 2013.

Accepted May 24, 2013.

Please include this information when citing this paper: DOI: 10.3171/2013.5.FOCUS13147.

Address correspondence to: Richard C. E. Anderson, M.D., The Neurological Institute, 710 West 168th St., Rm. 213, New York, NY 10032.email: rca24@columbia.edu. 